\title{
A Major Outer-membrane Protein Functions as a Porin in Haemophilus influenzae
}

\author{
By JANE L. BURNS* AND ARNOLD L. SMITH \\ Department of Pediatrics, University of Washington, Division of Infectious Disease, \\ Children's Hospital and Medical Center, 4800 Sand Point Way NE, Seattle, WA 98105, USA
}

(Received 21 July 1986; revised 29 December 1986)

\begin{abstract}
Porins are pore-forming outer-membrane proteins which serve as a non-specific pathway for the entry of hydrophilic molecules into Gram-negative bacteria. We studied four strains of Haemophilus influenzae that had decreased permeability to chloramphenicol associated with diminished quantities of a $40 \mathrm{kDa}$ major outer-membrane protein. Isogenic pairs of organisms containing and lacking this protein were compared. The latter strains grew more slowly and were less permeable to sucrose and raffinose. They were also more resistant to multiple hydrophilic antibiotics than an isogenic strain containing the $40 \mathrm{kDa}$ protein and were less permeable to penicillin $\mathrm{G}$ and chloramphenicol. We conclude that the $40 \mathrm{kDa}$ outer-membrane protein functions as a porin in $H$. influenzae.
\end{abstract}

\section{INTRODUCTION}

Haemophilus influenzae is an important Gram-negative pathogen. $H$. influenzae type $\mathrm{b}$ is the leading cause of bacterial meningitis in the United States, resulting in nearly 10000 cases per year; other systemic infections including epiglottitis, bacteraemia, pneumonia, septic arthritis and cellulitis afflict an additional 8000 children annually (Band et al., 1984; Granoff \& Basden, 1980). In addition, numerous serious infections in healthy and immunocompromised children and adults are caused by unencapsulated and non-type b capsulated $H$. influenzae (Bartlett $e t$ al., 1983; Liston \& Foshee, 1982; Shann et al., 1984).

$H$. influenzae has special nutritional requirements for growth including the addition of haem and $\beta$-NAD to culture media (Kilian, 1985). However, despite its fastidious growth requirements, Haemophilus shares many features with other Gram-negative organisms, including an outer membrane which regulates cell permeability. Pore-forming transmembrane proteins (porins) serve as a non-specific pathway for the entry of hydrophilic compounds (including nutrients and antibiotics) into Gram-negative bacterial cells. Porins from the Enterobacteriaceae are organized as trimers in the outer membrane with subunit molecular masses ranging from 34 to $42 \mathrm{kDa}$ (Nikaido \& Vaara, 1985).

We recently reported four clinical isolates of $H$. influenzae which demonstrate decreased accumulation of chloramphenicol in association with markedly diminished quantities of a $40 \mathrm{kDa}$ outer-membrane protein (Burns et al., 1985). To test the hypothesis that this protein functions as a porin which regulates the influx of chloramphenicol and other hydrophilic compounds into the periplasmic space, we examined the growth rate, oligosaccharide uptake, antibiotic susceptibility and penicillin permeability of strains containing and lacking the protein.

\section{METHODS}

Bacterial strains and plasmids. The strains utilized have been previously characterized (Burns et al., 1985). Strain MAP is a multiple antibiotic-resistant laboratory strain (Catlin et al., 1972) which is chloramphenicol susceptible. Strains 77-1040, 76-81739, 76-79268 and C435 are chloramphenicol-resistant clinical isolates (Burns et al., 1985). Transformant strains TF 77-1040-8, TF 76-81739-7, TF 76-79268-1 and TF C435-2 were constructed by 
transformation of strain MAP with whole-cell DNA from the chloramphenicol-resistant clinical isolates; these strains are deficient in the $40 \mathrm{kDa}$ outer-membrane protein (Burns et al., 1985). All are strains of $H$. influenzae, as determined by an absolute requirement for haem and $\beta$-NAD (Kilian, 1985), and all are unencapsulated as determined by agglutination with Difco typing sera. Bacterial strains were stored at $-80^{\circ} \mathrm{C}$ in vials of skim milk and freshly subcultured on solid media prior to each experiment.

Plasmid RSF007 (de Graaff et al., 1976), a 30 MDa conjugative plasmid encoding $\beta$-lactamase production, was used to introduce $\beta$-lactamase activity into strain MAP and TF 76-81739-7. Strain RSF007 was the source of this plasmid and was kindly provided by Dr Stanley Falkow, Department of Microbiology, Stanford University, Calif., USA.

Media. Liquid medium was brain heart infusion broth (Difco) supplemented with $10 \mu \mathrm{g}$ haemin, $10 \mu \mathrm{g} \mathrm{L}$ histidine and $10 \mu \mathrm{g} \beta$-NAD ml-1 (sBHI). Solid medium was sBHI agar. Broth cultures were incubated at $37^{\circ} \mathrm{C}$ with shaking at 200 cycles $\mathrm{min}^{-1}$. Plate cultures were incubated at $37^{\circ} \mathrm{C}$ in room air supplemented with $5 \%(\mathrm{v} / \mathrm{v})$ $\mathrm{CO}_{2}$.

Antibiotics and chemicals. Chloramphenicol, tetracycline. $\mathrm{HCl}$ and ampicillin sodium were obtained in crystalline form from Sigma. Cephalothin, cefaclor, cefamandole and moxalactam were supplied by Eli Lilly \& Co., cefuroxime by Glaxo, and cefotaxime by Hoechst-Roussel. $\left[{ }^{3} \mathrm{H}\right]$ Raffinose (specific activity 288.6 GBq mmol${ }^{-1}$ ) and $\left[{ }^{14} \mathrm{C}\right]$ sucrose (specific activity $133.2 \mathrm{GBq} \mathrm{mmol}^{-1}$ ) were purchased from New England Nuclear. Other chemicals, salts and buffers were of the purest form available from J. T. Baker Chemical Co. and Mallinckrodt Inc.

Growth rate determination. Flasks of $\mathrm{sBHI}$ broth $(100 \mathrm{ml})$ were inoculated with $1 \mathrm{ml}$ overnight broth culture and incubated at $37^{\circ} \mathrm{C}$. Using a Spectronic 20 spectrophotometer (Bausch \& Lomb), $\mathrm{OD}_{600}$ was recorded initially and at $30 \mathrm{~min}$ intervals once an increase in optical density was detected.

Determination of minimal inhibitory concentrations (MICs). MICs of nine hydrophilic antibiotics were determined by agar dilutions using a Steers replicator (Steers et al., 1959). The inoculum used was $10^{5}$ c.f.u. (Syriopoulou et al., 1979). Plates were incubated for 18-24 h and results were then recorded.

Conjugation. $\beta$-Lactamase activity was introduced into strains MAP and TF 76-81739-7 by conjugation. The technique used was a filter paper mating (Burns et al., 1985) with selection of transconjugant colonies by plating dilutions on $\mathrm{SBHI}$ agar containing ampicillin $\left(5 \mu \mathrm{g} \mathrm{ml}^{-1}\right)$ and chloramphenicol $\left(2 \mu \mathrm{g} \mathrm{ml}^{-1}\right)$. Transconjugants were examined for $\beta$-lactamase activity by the chromogenic cephalosporin assay (O'Callaghan et al., 1972).

$\beta$-Lactam permeability assay. The $\beta$-lactam permeability assay (Mendelman et al., 1984) compared spectrophotometrically the hydrolysis of penicillin $\mathrm{G}$ by periplasmic $\beta$-lactamase in whole cells to that in sonicated cell extracts. $K_{\mathrm{m}}$ and $V_{\max }$ were calculated for the hydrolysis of penicillin $\mathrm{G}$ in cell sonicates. The rate of hydrolysis in intact cells $\left(V_{\text {intact }}\right)$ at a substrate concentration of $1 \mathrm{~mm}\left(S_{0}\right)$ was recorded and the penicillin concentration inside the cells $\left(S_{e}\right)$ was calculated from the equation of Zimmermann \& Rosselet (1977):

$$
S_{\mathrm{e}}=\left[V_{\text {intact }} /\left(V_{\max }-V_{\text {intact }}\right)\right] \times K_{\mathrm{m}}
$$

Each assay was done in duplicate and repeated three times.

Uptake of oligosaccharides. A modification of the technique of Decad \& Nikaido (1976) was used to examine the uptake of $\left[{ }^{14} \mathrm{C}\right]$ sucrose $\left(M_{\mathrm{r}} 342 \cdot 3\right)$ and $\left[{ }^{3} \mathrm{H}\right]$ raffinose $\left(M_{\mathrm{r}} 504 \cdot 5\right)$. A $500 \mathrm{ml}$ broth culture of each organism was grown to mid-exponential phase (about $5 \times 10^{8}$ c.f.u. $\mathrm{ml}^{-1}$ ) and harvested by centrifugation. The organisms were washed and resuspended in $2 \mathrm{ml} 0.025 \mathrm{M}$-sodium phosphate buffer ( $\mathrm{pH} 7.0$ ). To $400 \mu \mathrm{l}$ cell suspension was added $1.5 \mu \mathrm{Ci}(55.5 \mathrm{kBq})\left[{ }^{14} \mathrm{C}\right]$ sucrose and $0.5 \mu \mathrm{Ci}(18.5 \mathrm{kBq})\left[{ }^{3} \mathrm{H}\right]$ raffinose; unlabelled sucrose and raffinose were added at a final concentration of $0.01 \mathrm{M}$ and $0.02 \mathrm{M}$, respectively. Cells were plasmolysed by the addition of $0.3 \mathrm{M}-\mathrm{NaCl}$. Samples were vortexed briefly, incubated for $5 \mathrm{~min}$ at room temperature and centrifuged at $12000 \mathrm{~g}$ for $3 \mathrm{~min}$. The supernatant $\left(S_{1}\right)$ was retained, the tube was carefully dried, and the pellet was resuspended in $1 \mathrm{ml}$ phosphate buffer. After $10 \mathrm{~min}$ at room temperature, the cells were again pelleted and a sample of supernatant was retained $\left(S_{2}\right)$. The radioactivity in $S_{1}$ and $S_{2}$ for each strain was separately determined by double-label counting in a Packard Tricarb scintillation spectrometer and the permeable space for sucrose and raffinose was calculated for each strain:

$$
\text { Permeable space }=\frac{\text { Total radioactivity in } S_{2}}{\text { Radioactivity } \mu l^{-1} \text { in } S_{1}}
$$

Colony counts were done following washing and resuspension of the original culture to enable interstrain comparison.

\section{RESULTS}

Growth rate. The growth rates of strain MAP and three transformant strains deficient in the $40 \mathrm{kDa}$ outer-membrane protein (40K OMP-) were compared (Fig. 1). In five separate experiments, the transformants consistently grew more slowly and achieved a lower $\mathrm{OD}_{600}$ than strain MAP. 


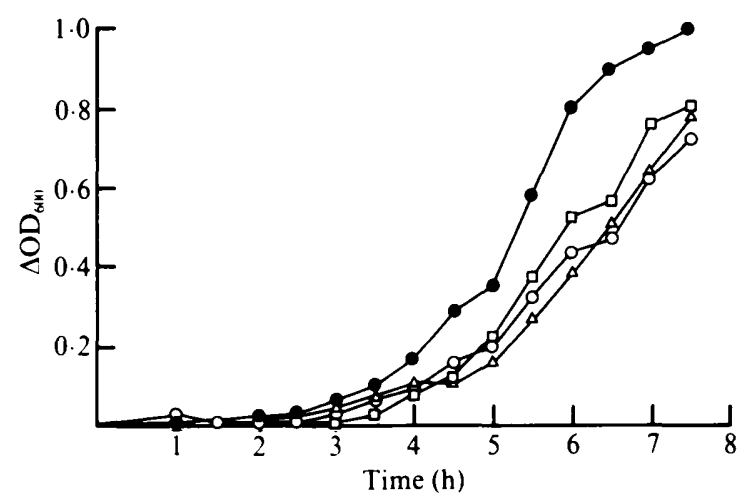

Fig. 1. Comparison of growth rate of strain MAP (O) with three 40K OMP-deficient strains: TF C435-2 $\square)$, TF 76-81739-7 $\triangle$ ) and TF 77-1040-8 (O). Culture flasks containing $100 \mathrm{ml} \mathrm{sBHI}$ were inoculated with $1 \mathrm{ml}$ from an overnight culture of each organism. $\mathrm{OD}_{600}$ was monitored and recorded over time.

Table 1. MIC values

Measurement was by the agar dilution method. A $10^{5}$ c.f.u. inoculum was applied by using a Steers replicator. $\mathrm{Cm}$, chloramphenicol; Tet, tetracycline; Amp, ampicillin; Cef, cephalothin; $\mathrm{Clr}$, cefaclor; Man, cefamandole; Crx, cefuroxime; Ctx, cefotaxime; Mox, moxalactam.

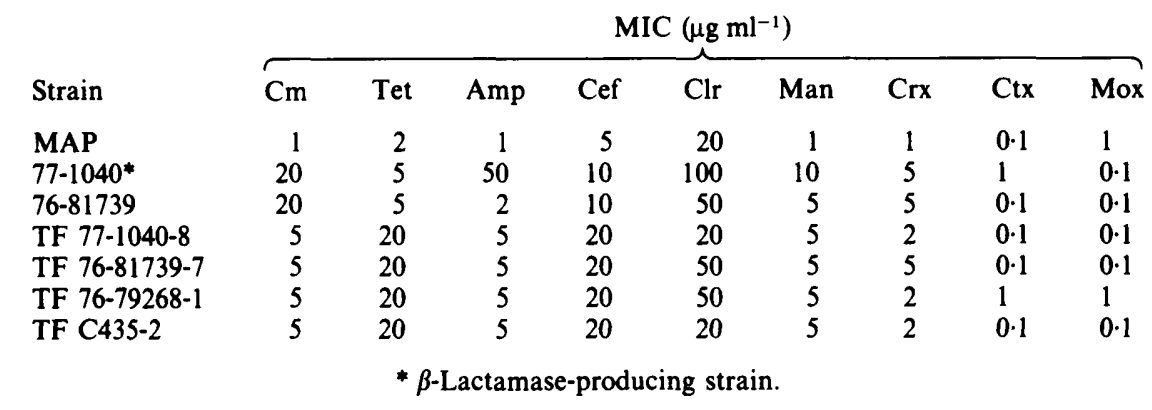

MICs. MICs of nine hydrophilic antibiotics for strain MAP, the chloramphenicol-resistant clinical isolates and the $40 \mathrm{~K}^{\mathrm{OMP}}$ - transformants are listed in Table 1 . The strains deficient in the $40 \mathrm{kDa}$ protein were less susceptible to chloramphenicol, tetracycline, ampicillin and firstand second-generation cephalosporins than strain MAP. Susceptibility to cefotaxime and moxalactam was equivalent. These results suggest a non-specific permeability barrier to many hydrophilic antibiotics in addition to chloramphenicol.

Permeability to penicillin $G$. The permeability of the outer membrane to penicillin $G$ was determined for strains MAP(RSF007) and TF 76-81739-7(RSF007). Each assay was done in duplicate and repeated three times. The calculated ratio of internal to external concentration of penicillin $\mathrm{G}\left(S_{\mathrm{e}} / S_{0}\right.$, mean $\left.\pm \mathrm{SD}\right)$ was $0.76 \pm 0.27$ for MAP(RSF007) and $0.05 \pm 0.03$ for TF 7681739-7(RSF007). The calculated minimum internal (periplasmic) concentration of penicillin $G$ for strain TF 76-81739-7 compared with that for strain MAP suggests an outer-membrane impermeability to $\beta$-lactam antibiotics as well as to chloramphenicol.

Permeability to oligosaccharides. The relative permeability to $\left[{ }^{14} \mathrm{C}\right]$ sucrose and $\left[{ }^{3} \mathrm{H}\right]$ raffinose of H. influenzae strains MAP and TF 76-81739-7 was compared; Escherichia coli strains C600 (Bachmann, 1972) and CmlB, a porin-deficient, chloramphenicol-resistant mutant (Reeve, 1968), served as controls (Table 2). Experiments were done in duplicate. Strains TF 76-81739-7 appeared to have decreased penetration of both sucrose and raffinose compared with strain MAP, supporting the hypothesis of a generalized permeability barrier to hydrophilic 


\section{Table 2. Permeability to radiolabelled oligosaccharides}

Permeability was determined by the technique of Decad \& Nikaido (1976). Each value was calculated from two determinations of the permeable space for radiolabelled oligosaccharides in a cell pellet containing $4 \times 10^{10}$ c.f.u.

$\begin{array}{lcc}\text { Strain } & \begin{array}{c}{\left[{ }^{14} \mathrm{C}\right] \text { Sucrose-permeable space }} \\ \left(\mu \mathrm{l} \text { per } 4 \times 10^{10} \mathrm{c.f} . \mathrm{u} .\right)\end{array} & \begin{array}{c}{\left[{ }^{3} \mathrm{H}\right] \text { Raffinose-permeable space }} \\ \left(\mu \mathrm{l} \text { per } 4 \times 10^{10} \mathrm{c.f} . \mathrm{u} .\right)\end{array} \\ \begin{array}{l}\text { H. influenzae } \\ \text { MAP }\end{array} & 64.0 & 53.4 \\ \text { TF 76-81739-7 } & 46.7 & 37.5 \\ \text { E. coli } & 71 \cdot 2 & 51.6 \\ \text { C600 } & 49.7 & 34.3 \\ \text { CmlB } & \text { * porin-deficient E. coli mutant (Reeve, 1968). }\end{array}$

compounds. In addition, for all four strains examined there was relatively lower permeability to raffinose than to the smaller saccharide, sucrose. However, in the $H$. influenzae strains, the difference was not as striking as in the $E$. coli strains. This is consistent with the existence of a higher exclusion limit in $H$. influenzae.

\section{DISCUSSION}

Porins were first identified in the Enterobacteriaceae, and porin physiology has been defined in $E$. coli and Salmonella typhimurium. There are two major porin proteins in E. coli K12, OmpF and OmpC (Lutkenhaus, 1977; Lugtenberg et al., 1975); in S. typhimurium there are three, 36K, $35 \mathrm{~K}$ and $34 \mathrm{~K}$ (Nakae \& Ishii, 1978). The proteins function as non-specific pores facilitating the diffusion of small hydrophilic molecules including saccharides, amino acids, nucleotides and antibiotics (Heuzenroeder \& Reeves, 1981; Nakae \& Nikaido, 1975; Nikaido et al., 1977; van Alphen et al., 1978). Nikaido and co-workers (Decad \& Nikaido, 1976; Nakae, 1976) determined the exclusion limit for enterobacterial porins to be 600-800 Da.

The role of porins in antibiotic susceptibility has been well characterized in the Enterobacteriaceae: porin-deficient mutants with altered outer-membrane permeability have been selected using antibiotic resistance as a marker. $E$. coli mutants deficient in OmpF, OmpC, or both, exhibit decreased penetration of hydrophilic antibiotics including $\beta$-lactams, tetracycline and chloramphenicol, with resultant phenotypic resistance (Chopra \& Eccles, 1978; Nikaido et al., 1983; Reeve, 1968). S. typhimurium mutants deficient in the $36 \mathrm{~K}$ and $34 \mathrm{~K}$ proteins, together or singly, have decreased permeability to $\beta$-lactams (Nikaido et al., 1977).

Vachon et al. (1985) reported a $40 \mathrm{kDa}$ protein present in outer-membrane fractions that formed transmembrane permeability channels in $H$. influenzae type $\mathrm{b}$. When this protein was introduced into reconstituted vesicles, they became permeable to sucrose, raffinose and stachyose $\left(M_{\mathrm{r}} 666\right)$ but fully retained dextrans larger than $1500 \mathrm{Da}$.

We previously reported four unencapsulated clinical isolates of $H$. influenzae, having decreased permeability to chloramphenicol associated with the apparent absence of a $40 \mathrm{kDa}$ major outer-membrane protein (Burns et al., 1985). The data we present here confirm the hypothesis that this protein functions as a porin in vivo. Strains lacking the protein exhibit a slower growth rate and a relative decrease in accumulation of saccharides in addition to a generalized decrease in antibiotic susceptibility and a specific decrease in penicillin $G$ permeability. Thus, the $40 \mathrm{~K} \mathrm{OMP}^{-}$strains are deficient in two porin-mediated functions: nutrient uptake and antibiotic accumulation.

We conclude that the $40 \mathrm{kDa}$ major outer-membrane protein functions as a porin in $H$. influenzae. The growth of 40K OMP-deficient strains in the laboratory and their ability to infect patients suggest that alternative porins (either constitutive or inducible) function in these strains.

This research was supported in part by Public Health Service Grants AI 06726 and AI 20625 from the National Institutes of Health. 


\section{REFERENCES}

van Alphen, W., van Selm, N. \& Lugtenberg, B. (1978). Pores in the outer membrane of Escherichia coli K12. Molecular and General Genetics 159, 75-83.

Bachmann, B. J. (1972). Pedigrees of some mutant strains of Escherichia coli K-12. Bacteriological Reviews 36, 525-557.

Band, J. D., Fraser, D. W., Ajello, G. \& the Haemophilus Influenzae Disease Study Group (1984). Prevention of Hemophilus influenzae type b disease. Journal of the American Medical Association 251, 2381-2386.

Bartlett, A. V., Zusman, J. \& Daum, R. S. (1983). Unusual presentations of Haemophilus influenzae infections in immunocompromised patients. Journal of Pediatrics 102, 55-58.

Burns, J. L., Mendelman, P. M., Levy, J., Stull, T. L. \& SMITH, A. L. (1985). A permeability barrier as a mechanism of chloramphenicol resistance in Haemophilus influenzae. Antimicrobial Agents and Chemotherapy 27, 46-54.

Catlin, B. W. (1973). Nutritional profiles of Neisseria gonorrhoeae, Neisseria meningitidis, and Neisseria lactamica in chemically defined media and the use of growth requirements for gonococcal typing. Journal of Infectious Diseases 128, 178-194.

Catlin, B. W., Bendler, J. W., III \& Goodgal, S. H. (1972). The type b capsulation locus of Haemophilus influenzae: map location and size. Journal of General Microbiology 70, 411-422.

Chopra, I. \& ECCLES, S. J. (1978). Diffusion of tetracycline across the outer membrane of Escherichia coli K-12: Involvement of protein $\mathrm{I}_{\mathrm{a}}$. Biochemical and Biophysical Research Communications 83, 550-557.

DeCaD, G. M. \& NiKaIDO, H. (1976). Outer membrane of Gram-negative bacteria. Journal of Bacteriology 128, 325-336.

de Graaff, J., Elwell, L. P. \& Falkow, S. (1976). Molecular nature of two beta-lactamase-specifying plasmids isolated from Haemophilus influenzae type b. Journal of Bacteriology 126, 439-446.

GranofF, D. M. \& BASDEN, M. (1980). Haemophilus influenzae infections in Fresno County, California: a prospective study of the effects of age, race, and contact with a case on incidence of disease. Journal of Infectious Diseases 141, 40-46.

Heuzenroeder, M. W. \& ReEves, P. (1981). The $t s x$ protein of Escherichia coli can act as a pore for amino acids. Journal of Bacteriology 147, 1113-1116.

KILIAN, M. (1985). Haemophilus. In Manual of Clinical Microbiology, pp. 387-393. Edited by E. H. Lennette, A. Balows, W. J. Hausler \& H. J. Shadomy. Washington, DC: American Society for Microbiology.

Liston, T. E. \& Foshee, W. S. (1982). Invasive disease due to nontypable Haemophilus influenzae in children. Southern Medical Journal 75, 753-754.

Lugtenberg, B., Meijers, J., Peters, R., van der HoEk, P. \& VAN AlPhen, L. (1975). Electrophoretic resolution of the major outer membrane protein of
Escherichia coli $\mathrm{K} 12$ into four bands. FEBS Letters 58, 254-258.

LUTKENHAUS, J. F. (1977). Role of a major outer membrane protein in Escherichia coli. Journal of Bacteriology 131, 631-637.

Mendelman, P. M., Chaffin, D. O., Stull, T. L., Rubens, C. E., MaCK, K. D. \& SMITH, A. L. (1984). Characterization of non- $\beta$-lactamase-medicated ampicillin resistance in Haemophilus influenzae. Antimicrobial Agents and Chemotherapy 26, 235-244.

NAKAE, T. (1976). Identification of the outer membrane protein of $E$. coli that produces transmembrane channels in reconstituted vesicle membranes. Biochemical and Biophysical Research Communications 71, 877-884.

NAKAE, T. \& IsHII, J. (1978). Transmembrane permeability channels in vesicles reconstituted from single species of porins from Salmonella typhimurium. Journal of Bacteriology 133, 1412-1418.

NAKaE, T. \& NikaIDO, H. (1975). Outer membrane as a diffusion barrier in Salmonella typhimurium. Journal of Biological Chemistry 250, 7359-7365.

Nikaido, H. \& VaARa, M. (1985). Molecular basis of bacterial outer membrane permeability. Microbiological Reviews 49, 1-32.

Nikaido, H., Song, S. A., Shaltiel, L. \& Nurminen, M. (1977). Outer membrane of Salmonella. XIV. Reduced transmembrane diffusion rates in porindeficient mutants. Biochemical and Biophysical Research Communications 76, 324-330.

Nikaido, H., Rosenberg, E. Y. \& Foulds, J. (1983). Porin channels in Escherichia coli: studies with $\beta$ lactams in intact cells. Journal of Bacteriology 153, 232-240.

O'Callaghan, C. H., Morris, A., Kirby, S. M. \& SHINGLER, A. H. (1972). Novel method for detection of $\beta$-lactamases by using a chromogenic cephalosporin substrate. Antimicrobial Agents and Chemotherapy 1, 283-288.

REEVE, E. C. R. (1968). Genetic analysis of some mutations causing resistance to tetracycline in Escherichia coli K12. Genetical Research 11, 303-309.

Steers, E., Foltz, E. L. \& Graves, B. S. (1959). An inocula replicating apparatus for routine testing of bacterial susceptibility to antibiotics. Antibiotics and Chemotherapy 9, 307-311.

Syriopoulou, V. Ph., Scheifele, D. W., Sack, C. M. \& SMITH, A. L. (1979). Effect of inoculum size on the susceptibility of Haemophilus influenzae b to betalactam antibiotics. Antimicrobial Agents and Chemotherapy 16, 510-513.

Vachon, V., Lyew, D. J. \& Coulton, J. W. (1985). Transmembrane permeability channels across the outer membrane of Haemophilus influenzae type b. Journal of Bacteriology 162, 918-924.

ZimmermanN, W. \& Rosselet, A. (1977). Function of the outer membrane of Escherichia coli as a permeability barrier to beta-lactam antibiotics. Antimicrobial Agents and Chemotherapy 12, 368-372. 